\title{
Quality of Life: Healthy Relationship with Ourselves
}

Only healthy individuals are capable of establishing and maintaining healthy relationships. Behind every impaired relationship impaired individual(s) can be detected. This is why the starting point of the healing process is the impaired individual, or more precisely, the impaired relationship and its personal implications. The fragments of these personal stories belong partly to the conscious and partly to the unconscious. Our aim is to reframe these contents because this is the essence of healing. Reframing the conscious may happen verbally, whereas in the case of the unconscious it usually takes a visual form, since images constitute the language of the unconscious. The reframed personality is healthier, is more tolerant with himself/herself, and has an improved quality of life. He/she suffers less, has more joy in life, and it all takes place in real life. The study illustrates these points with the help of models and case studies.

\section{Development model}

Throughout my developing and coaching work the individual is the focus of my attention. Even in a psychodrama group the individual (as the main character of the drama) is in the centre of development. The same is true for couple therapy where the primary goal is that both members of the couple become mature individuals. A mature individual should meet the following criteria:

- is able to make decisions

- takes responsibility for decisions

- accepts the other person(s) freedom to make decisions

Instead of ,we'd better stay together" we are therefore aiming to reach the point where two mature individuals decide to stay together. The relationship of codependent couples relies on vulnerability, which could also be labeled trust or naiveté once the relationship is over.

On the basis of the above statements we can say that only Healthy Individuals (HI) are capable of establishing and maintaining Healthy Relationships (HR).

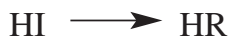

On the basis of the opposite of the above statement we can say that Impaired Individuals (II) establish and maintain Impaired Relationships (IR). 


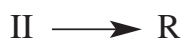

Some characteristics of impaired relationships are as follows:

- distorted or obscure relationships and roles

- hidden or open aggression, fear, compliance, guilt

- excess pain and suffering, less joy

The opposite of the basic statement implies that behind impaired relationships impaired individuals can be detected. Yet the impaired individual is not only a cause but also a result. Individual impairments are the result of impaired relationship(s) in the personal history. The process can be illustrated on a time line:

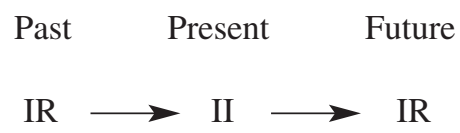

The individual stores the consequences of past impaired relationship(s) in Impaired Contents (IC). These sometimes conscious but mostly unconscious contents bear the person's impairments even if they are represented as fragments or in symbolic forms. Our aim is to reframe these contents because this is the essence of healing. Reframing the conscious may happen verbally, whereas in the case of the unconscious it usually takes a visual form, since images constitute the language of the unconscious.

Development activity aims at reframing these impaired contents by means of Interventions (I). In the case of successful interventions the impaired contents are rewritten and accepted, and they become healthy (Reframed) Contents (RC) in the individual's development process. This way the Healthy Individual (HI) is potentially ready for Healthy Relationship(s) (HR). The complete model can be seen below:

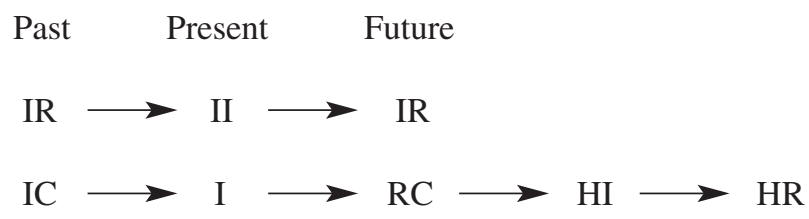

I use the following types of interventions in my practice: counseling, training, coaching, psychodrama, and personal development. These methods have their own techniques, and as a result, their impacts are different. Counseling and training target the personality's on-stage, dressing room and blind areas. Psychodrama and personal development go beyond them and activate the unconscious of the individual. Coaching in my view is a borderline activity. 


\section{Explanatory models}

My development activity is based on Jung's personality models, and I have modified the Johari model to illustrate the main points. The modified version provides a synthesis for Jung's personality model, the drama approach and the dynamic explanations.

The Johari window shows that in the two dimensions our selves can be divided into four areas:

Figure 1. Johari window (Rudas, 1997, 38.)

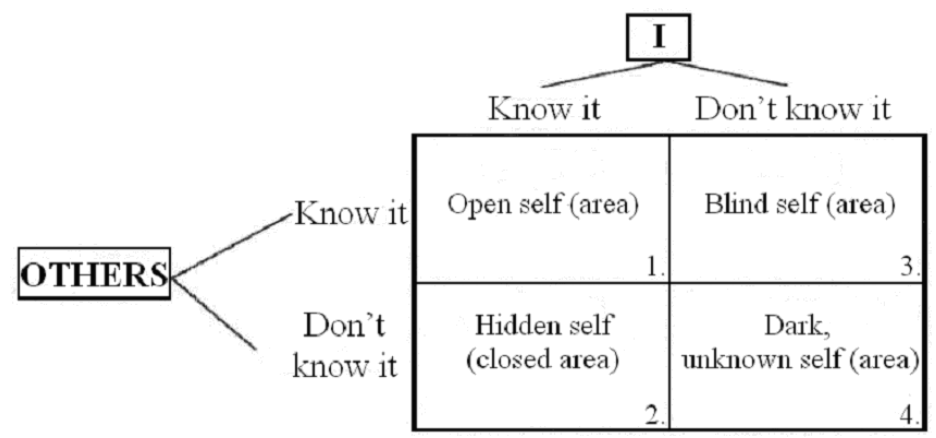

The first quarter represents those parts of the personality which the individual is aware of and is willing to share with others: this is the "open self". This is the area of an individual's behavior that is well-know by the individual and others around him/her.

The second quarter represents those parts of the personality which are known by the individual but is not willing to share with others: consciously or unconsciously hides it from others. It is a highly confidential area.

The third quarter shows the blind area of the self, containing those aspects of the individual's behavior and style that are known by others but $\mathrm{s} / \mathrm{he}$ is not willing to recognize and admit.

The fourth quarter is the dark, unknown area: unknown to us and to others.

The boundaries between the four areas are not rigid. Throughout the training, when the individual becomes aware of these boundaries, they move in such a way that results in the expansion of the open self, thus the hidden and blind areas become smaller. This is, therefore, a dynamic model, and the internal boundaries can be explained this way. The boundary between the first and second quarters is a line of trust, depending on the group, and has a specific movement. It can go up and down, slowly or rapidly, following the changes in the trust persons feel towards each other 
(trust growing or depleting). Several real-life situations can be explained with its help. The vertical line can also by explained dynamically, as it stands for self-knowledge. Its slow movement enables us to move certain elements of the blind and dark areas into the open or hidden self area. This is Jung's individuation process, through which one becomes an individual self. We get to know our previously unknown self: our shadow and role personalities and our dominant archetypes. This is the road one has to take when getting to one's true, inner self what Jung called the Selbst.

According to Jung, if we depict personality as a blunt pyramid, the triangle near the peak is the conscious where the self takes a central position, and in its peak we can find the persona through which the conscious self communicates with the outside world. Well below the area of the conscious spreads the individual unconscious, containing the complexes, and all the forgotten or suppressed memories. The individual unconscious contains our shadow, with its borders reaching the collective unconscious, which occupies the rest of the pyramid downwards and has no boundaries. Archetypes constitute our collective unconscious, and the complex of the anima vs. animus function reacts with the individual unconscious and moves towards the conscious.

Figure 2. Jung’s personality model (Pszichoterápia, 1996.)

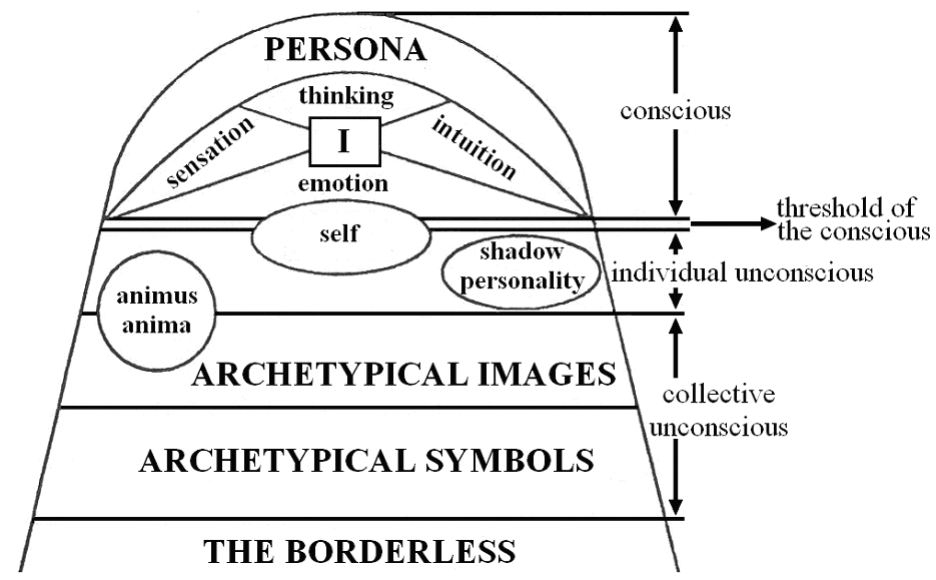

Trainings cover the open, hidden and blind areas of the Johari model, or to rephrase it with the terminology of drama technique, they operate in the individual's onstage, dressing room and blind areas. We focus our activity on these three areas which stand for the level of behavior, and have nothing to do with the fourth (dark) area. We cannot work on the latter area as our contract with the client is about reframing behavior and not about reframing personality. Our aim is to reach a more 
efficient behavior; we do not aim at revealing the reasons for the individual's behavior. The three clearly yet dynamically distinguished areas of behavior (onstage, dressing room, and blind) merely complement each other, but do not cover the unconscious reasons for these behavior types. These can be found in the dark area which corresponds with Jung's personal unconscious theory. This is a huge area, manifold the size of the conscious. Figure 3 shows a revised model, based on the combination of drama categories and Jung's personality model.

Figure 3. Revised model (Titkos, 2009, 75.)

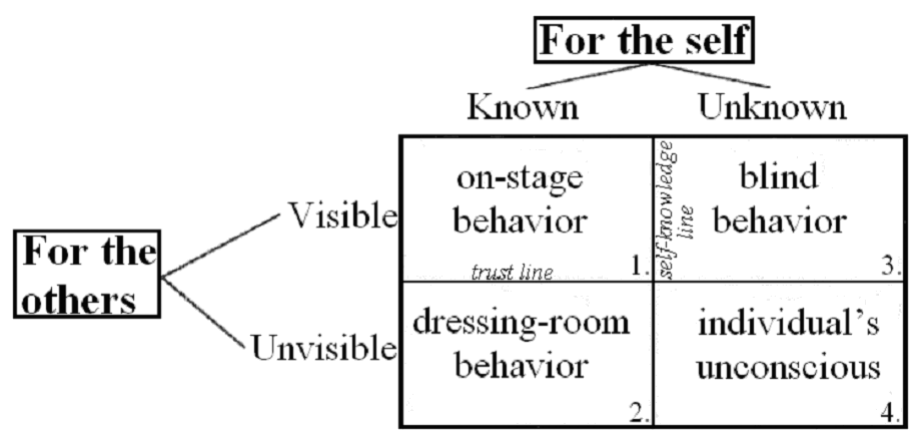

\section{Personality development}

The area where the unconscious reasons for our behavior (the roots of our personality) can be found is analogous with Jung's deep structure, yet this is the area that goes beyond the means and power of training. If we wish to develop one's personality, this is the area we have to focus on, but it needs specific approaches, ones which are able to communicate with this area, and have been developed to reframe the area beyond behavior.

Sometimes unintended events, for example, accidents may lead to some parts of the dark area come to light. Nevertheless, several specific procedures are at our disposal if we wish to reveal the hidden aspects of one's personality, namely analysis, psychodrama, kinesiology, hypnosis, NLP, KIP, and EGO-state. These are used mostly in therapy, but some of them - NLP and psychodrama - can be used in trainings to some extent.

In my view it is important to clarify what we mean by therapy, because some may find it intimidating. Any friendly conversation may have a therapeutic effect if it contains (albeit unconsciously) Rogers's three principles: 
- Empathy

- Unconditional acceptance

- Congruence

Therapy, of course, has different levels, although this may be detected only by the therapist and only with regard to how difficult the process is. Yet the therapeutic intention is likely to be the same, whether it comes from a friend or from a professional.

Psychodrama, applying psychotherapeutic techniques, individual personality development and coaching are likely to reveal unconscious contents. The first two methods are designed to do that. These two methods attempt to reveal and heal impaired relationships, enabling the individual to have healthy relationships.

\section{Case studies}

First case: training at a department level of a large Hungarian financial institution. The topic is how to debate and argue effectively. The members of the group are debating and persuading each other, competitively rather then cooperatively. The on-lookers in the pair activity are also getting involved, opinions are polarized, the group is divided into two. This division becomes physically detectable. The participants are now arguing representing two (physically and emotionally) confronting groups, which is not the typical way this activity is carried out. They are becoming more and more vehement and irritated. One of them seems to be too much involved emotionally, so much so that against one of the rules of the training, keeps on saying negative remarks to one member of the other group. I stop the activity and ask the person who gives these remarks to have a good look at the one being targeted: who is the real addressee of these remarks? After some silence the answer is:"my younger brother". The most important result of the training for him is acknowledging that he has projected his anger towards his younger brother onto someone else, although he believed he had already settled the case with his sibling. I tell him that he still has to do that, but this is not the task of the training, so we can go on with the activity.

Second case: headquarters of a significant company in the energy sector. A selection process is taking place, a decision has to be made, yet the process turns into coaching. Analyzing the decision making process turns into a personal analysis. The question revealed the dilemma of the decision maker, his doubts, and his typical reactions in such situations. The analysis of these reactions helps the person recognize certain correspondences and is forced to do self-disclosure. The situation takes on a question and answer pattern, and soon shifts into therapeutic atmosphere. Finally, when we reach the end of coaching, a decision is also reached. 
Third case: individual personality development with integrative technique. The therapy takes place in a relaxed state of mind, with the help of imaginative method. Imagination is our innate skill. In the visual world created for therapeutic purposes we work in the client's unconscious, in a daylight-dream world, under the guidance of the therapist. The client can see the images, hears voices, can touch, taste and smell. S/he can be involved in the process in an associative or a dissociative way, while having a conversation with the therapist. S/he is at the level of daytime and of dreaming at the same time. (S/he knows s/he is therapy, but is also present in the story.) Imagination means regression into the early stage of visualization. Visualization is a mediator between unconscious contents and their conscious representation. It enables the compensation of early emotional losses, the belated maturation of personality structure, and the visual solution of conflicts.

The client works for a major bank in Hungary, and has problems with giving presentations. We are working in a modified state of mind. The imaginative situation is a group presentation in a Western European city. She is terrified while waiting for her turn and fears she will fail to do it right. I am asking her to have a look at herself and tell me how old she is. She is there as a girl of 8. Controlled regresssion is taking place. She is sitting in front of the TV as an eight-year-old girl and is frustrated. As an adult, she goes back and gives the girl what she needs (she plays with her) until the girl becomes satisfied. We are going back to the first imagination: she is already an adult, can give the presentation well, she is paid attention to, she is successful, gets applause, and comes back with positive feelings. The therapy goes on for several occasions. It turns out that age 8 is significant due to other reasons: death, accident, sibling rivalry. Getting attention and being helpless (accident) are connected in her unconscious. Giving a presentation is an activity which brings attention, therefore, it is not advantageous if it is connected with the feeling of being helpless. What used to bring attention in the childhood is now a dysfunctional behavior. The goal of personality development here is to understand and reframe the reasons of a fixated behavior leading to failure, thus giving way to the appearance of a new type of behavior.

\section{Bibliography}

Aronson, Elliot (2002): A társas lény. Budapest, KJK.

BíRÓ GyUla (é. n.): Rövid pszichoterápiák strukturált szintézise, avagy az NLP alapgondolatai. Kézirat.

BölCS ERIK (é. n.): Katatim imaginatív pszichoterápia (KIP). Kézirat.

DAUbNeR BÉlA-KAlO JENŐ (2005): A tudattalan nehezen járható ösvényén. Budapest, IPE.

FELdMÁR ANDRÁs (2004): Apró részletekben. Budapest, Könyvfakasztó.

Jung, CARl Gustav (1987): Emlékek, álmok, gondolatok. Budapest, Európa.

O’Connor, Joseph-Seymour, John (1996): NLP. Budapest, Bioenergetic. 
Rogers, CARL (2004): Valakivé válni. A személyiség születése. Budapest, SHL. RudAs János (1997): Delfi örökösei. Budapest, Gondolat-Kairosz.

TitKos Csaba (2006): Tréning - önismeret - viselkedés - személyiség - csoportjelenségek. Pécs, PTE KTK.

Titкos Csaba (2009): A személyiség Kaizen-elve. Vezetés Tudomány 40 (7-8), 67-77.

Pszichoterápia-Propedeutika 1. (1996): Budapest, Vikote. 